Intecoms: Journal of Information Technology and Computer Science

Volume 1 Nomor 2, Desember 2018

e-ISSN : 2614-1574

p-ISSN : 2621-3249

DOI : https://doi.org/10.31539/intecoms.v1i2.440

\title{
PENERAPAN E-LEARNING MATA KULIAH MATEMATIKA EKONOMI BAGI MAHASISWA EKONOMI DAN BISNIS ISLAM
}

\section{IMPLEMENTATION OF E-LEARING IN THE ECONOMIC MATHEMATICAL COURSE FOR ISLAMIC ECONOMIC AND BUSINESS STUDENTS}

\author{
Andang Sunarto \\ IAIN Bengkulu \\ andang99@gmail.com
}

\begin{abstract}
Economics mathematics courses are abstract and require high thinking activities. Nevertheless, all students studying in the Islamic Economics study program FEBI IAIN Bengkulu must learn it because it is one of the compulsory subjects in the Islamic Economics program FEBI IAIN Bengkulu that must be taken. Learning mathematics economics needs to need learning media that can improve students' understanding in learning economic mathematics. With the media, students are given the ease of visualization of the material presented, including series, linear functions and things needed in economic mathematics learning. accurate for users so that they can be used as a choice of learning media in teaching and learning processes, inspire lecturers to use web media in the teaching and learning process and students can study anywhere without being limited by space and time. The method used is research and development or in English Research and Development is a research method that is used to produce certain products, and test the effectiveness of these products used in this study is the software used in this application is moodle, xampp and internet.
\end{abstract}

Keywords :Moodle, Xampp, Internet.

\begin{abstract}
ABSTRAK
Mata kuliah matematika ekonomi adalah sesuatu yang abstrak dan memerlukan kegiatan berfikir yang tinggi. Meskipun demikian, semua mahasiswa yang belajar diprogram studi Ekonomi Islam FEBI IAIN Bengkulu harus mempelajarinya karena merupakan salah satu mata kuliah wajib di program studi Ekonomi Islam FEBI IAIN Bengkulu yang harus ditempuh. Belajar matematika ekonomi perlu membutuhkan media pembelajaran yang dapat meningkatkan pemahaman mahasiswa dalam belajar matematika ekonomi. Dengan media, mahasiswa diberikan kemudahan visualisasi materi yang disajikan diantaranya deret, fungsi linear dan hal-hal yang diperlukan dalam pembelajaran matematika ekonomi.Tujuan dari penelitian ini adalah pembuatan media pembelajaran matakuliah matematika berbasis web ekonomi, sehingga menghasilkan media pembelajaran yang lebih menarik, menarik dan akurat bagi pengguna sehingga dapat digunakan sebagai pilihan media pembelajaran dalam pengajaran dan proses pembelajaran, menginspirasi dosen untuk menggunakan media web dalam proses belajar mengajar dan siswa dapat belajar di mana saja tanpa dibatasi oleh ruang dan waktu. Metode yang digunakan adalah penelitian dan pengembangan atau dalam bahasa inggrisnya Research and Development adalah metode penelitian yang digunakan untuk menghasilkan produk tertentu, dan menguji keefektifan produk tersebut yang digunakan dalam penelitian ini adalah Perangkat lunak yang digunakan dalam aplikasi ini adalah moodle, xampp dan internet.
\end{abstract}

Kata Kunci :Moodle, Xampp, Internet.

\section{PENDAHULAN}

Belajar disadari atau tidak
merupakan kebutuhan manusia,
kemajuan- kemajuan yang telah diraih
pada masa ini merupakan hasil proses
belajar yang telah dilakukan manusia

berabad-abad yang lalu. Manusia pada dasarnya mempunyai sifat selalu ingin tahu yang mendorong manusia untuk terus belajar, bahkan pada hakikatnya kita akan terus belajar sampai akhir hayat kita. Belajar pada dasarnya 
dibedakan kedalam dua ketegori yaitu belajar secara mandiri (autodidak) dan belajar yang dilakukan secara formal disekolah atau pendidikan dan latihan yang diselenggarakan oleh suatu instansi atau lembaga pendidikan.

Dalam usaha meningkatkan kualitas masyarakat, pemerintah telah menyediakan berbagai sarana dan prasarana pendidikan baik formal maupun nonformal. Seperti tertuang dalam tujuan pendidikan nasional yang menyatakan bahwa:

Pendidikan nasional bertujuan mengembangkan kemampuan dan membentuk watak serta peradaban bangsa yang bermartabat dalam mencerdaskan kehidupan bangsa, bertujuan untuk berkembangnya potensi peserta didik agar menjadi manusia yang beriman dan bertaqwa kepada Tuhan yang Maha Esa, berakhlak mulia, sehat, berilmu cakap, kreatif, mandiri dan menjadi warga negara yang demokratis serta bertanggung jawab.

Untuk pencapaian tersebut, dosen berperan penting terutama dalam proses belajar mengajar. Dosen menempati posisi sentral sehingga diharuskan mampu menterjemahkan dan menjabarkan nilai-nilai yang terdapat dalam kurikulum, kemudian menyampaikan nilai-nilai tersebut kepada mahasiswa melalui proses pengajaran di perguruan tinggi. Begitu pula dengan sarana dan prasarana.

Jika dosen, mahasiswa dan kurikulum sudah baik, maka sarana dan prasarana juga harus menunjang demi terciptanya pendidikan yang berjalan dengan lancar tanpa hambatan apapun. Sarana dalam proses pembelajaran (dalam hal ini media pembelajaran) sangatlah penting, karena melalui media inilah ilmu yang diberikan oleh dosen bisa diterima dengan baik ataupun tidak oleh mahasiswa.
Selanjutnya salah satu ilmu yang ada di program studi ekonomi islam, fakultas ekonomi dan bisnis islam adalah matematika ekonomi. Banyak peserta didik yang memandang matematika ekonomi sebagai bidang studi yang sulit sehingga tidak sedikit dari mereka yang tidak menyukai matematika ekonomi. Ketidaksukaan para peserta didik timbul dari kesulitankesulitan yang mereka hadapi dalam menyelesaikan soal-soal yang diberikan, kondisi belajar yang kurang baik secara fisik, sosial dan emosional juga sarana dan prasarana yang kurang memadai menjadi salah satu faktor kesulitan mahasiswa dalam memahami matematika ekonomi.

Banyaknya pokok bahasan dan rumus yang harus diterima peserta didik juga merupakan salah satu penyebab kesulitan mashasiswa dalam belajar matematika ekonomi. Meskipun demikian, semua orang harus mempelajarinya karena merupakan sarana untuk memenuhi kebutuhan hidup sehari-hari.

Seiring dengan perkembangan Teknologi Informasi dan Komunikasi, metode belajar terus berkembang baik metode belajar untuk personal maupun metode yang lebih pada proses belajar secara keseluruhan atau Proses Belajar Mengajar (PBM), kurikulum sebagai penunjang Proses Belajar Mengajar pun terus mengalami perubahan dengan tujuan mencari kurikulum yang terbaik.

Pada proses belajar mengajar biasanya tatap muka menjadi sesuatu yang harus terjadi, karena bisa dipastikan tanpa ada tatap muka proses belajar mengajar akan sulit dilakukan. Perkembangan Teknologi yang pesat perlahan namun pasti mulai bisa mengubah paradigm tersebut, dimana proses belajar mengajar tidak harus lagi dibatasi oleh ruangan kelas belajar bisa dilakukan tanpa harus bertatap muka 
secara langsung dan bisa berlangsung dimana saja yang dikenal sebagai elearning

Lanjutan diatas menunjukan bahwa salah satu ilmu yang selalu diajarkan di perguruan tinggi dan disetiap jenjang pendidikan S1 program studi ekonomi islam adalah matematika ekonomi. Matematika ekonomi adalah sesuatu yang abstrak dan memerlukan kegiatan berfikir yang tinggi. Meskipun demikian, semua orang harus mempelajarinya karena merupakan sarana untuk memenuhi kebutuhan hidup sehari-hari. Belajar matematika ekonomi juga membutuhkan media pembelajaran yang dapat meningkatkan pemahaman mahasiswa dalam belajar matematika ekonomi. Dengan media, mahasiswa diberikan kemudahan visualisasi materi yang disajikan diantaranya deret, fungsi linear dan hal-hal yang diperlukan dalam pembelajaran matematika ekonomi.

Kemudian berdasarkan hasil observasi yang dilakukan di program studi Ekonomi Islam semester V FEBI IAIN Bengkulu mata kuliah Matematika Ekonomi, mahasiswa cenderung kurang aktif dan kurang berinteraksi dengan mahasiswa lain selama proses pembelajaran berlangsung karena dosen masih menerapkan metode pembelajaran teacher centered yaitu metode pembelajaran yang lebih dominan dosen sehingga mahasiswa kurang berperan dalam proses pembelajaran. Mahasiswa yang memiliki motivasi untuk mengikuti pembelajaran beberapa ada yang sudah nampak, namun ada pula yang masih kurang memperhatikan proses pembelajaran. Sebagian dari mahasiswa yang kurang memperhatikan pelajaran tersebut malah membuka game dan online untuk browser atau aktif dengan media sosialnya.
Salah satu inovasi model pembelajaran yang dapat diterapkan untuk memperbaiki metode pembelajaran teacher centered yaitu model pembelajaran online melalui penerapan E-learning. Seperti yang dilakukan oleh Teguh Arfianto, Handayanto dkk, M Prayitno, Setiawan, dengan model pembelajaran yang inovatif ini memberikan kondisi belajar aktif dan meningkatkan kompetensi sikap sosial mahasiswa karena mahasiswa dituntut untuk aktif berpendapat dan berusaha menemukan solusinya tentunya dengan bekerja sama dengan kelompoknya sehingga dapat meningkatkan hasil belajar mahasiswa tersebut.

\section{METODE PENELITIAN}

Penelitian ini menggunakan metode penelitian pengembangan model dengan disain pengembangan dan aplikasi. Metode penelitian dan pengembangan atau dalam bahasa inggrisnya research and development adalah metode penelitian yang digunakan untuk menghasilkan produk tertentu, dan menguji keefektifan produk tersebut. ]

Penelitian dilakukan di Program Studi Ekonomi Islam, Fakultas Ekonomi dan Bisnis Islam IAIN Bengkulu. Populasi dalam penelitian ini adalah seluruhmahasiswa semester V Program Studi Ekonomi Islam, FEBI IAIN Bengkulu.

Sampel yang digunakan dalam penelitian ini adalah tiga kelas mahasiswa Semester V Program Studi Ekonomi Islam, FEBI IAIN Bengkulu dansebanyak 120 mahasiswa.

\section{Perencanaan dan Penyusunan Model}

Pembuatan media pembelajaran mata kuliah matematika ekonomi berbasis web ini mengambil 
mengambil langkah-langkah sebagai berikut:

\section{MenentukanTema}

Penentuan tema digunakan untuk menganalisa gagasan, meliputi identifikasi kebutuhan dan karakteristik pengguna (user), menentukan materi pengajaran, dan memilih program komputer yang akan digunakan untuk membuat web pembelajaran mata kuliah matematika ekonomi. Sasaran user utama yang akan menggunakan web pembelajaran mata kuliah matematika ekonomi adalah mahasiswa semester $\mathrm{v}$ Program Studi Ekonomi Islam, FEBI IAIN Bengkulu. Selain bagi mahasiswa web pembelajaran mata kuliah matematika ekonomi ini juga akan membantu dosen memproyeksikan ide-ide pengajarannya kepada mahasiswa dalam menyampaikan materi mata kuliah matematika ekonomi.

Materi yang disediakan dalam web pembelajaran mata kuliah matematika ekonomi adalah materi deret dan fungsi linear. Hal ini dilakukan karena pada materi materi deret dan fungsi linear terdapat konsep-konsep dasar yang membutuhkan penjelasan lebih detail dan jelas. Fasilitas gambar serta animasi yang dimiliki web pembelajaran mata kuliah matematika ekonomi ini diduga dapat memenuhhi kebutuhan visual tersebut. Web pembelajaran mata kuliah matematika ekonomi ini dibuat dengan menggunakan program moodle.

\section{Mengumpulkan Bahan}

Pada tahap ini dilakukan pengumpulan bahan seperti gambar, animasi dan literature yang diperlukan pada pembuatan web ini. Materi pelajaran yang ada pada web pembelajaran mata kuliah matematika ekonomi ini adalah materi deret dan fungsi linear yang terdiri dari konsep dasar, contoh soal dan latihan soal yang telah dipersiapkan dan diambil dari beberapa referensi yang biasa digunakan oleh dosen untuk mahasiswa.

\section{Perancangan Desain}

Pada tahap ini dilakukan spesifikasi dari arsitektur dan gaya yang akan digunakan dalam membuat media pembelajaran mata kuliah matematika ekonomi berbasis web. Spesifikasi dibuat secara rinci sehingga pada tahap berikutnya, yaitu pengumpulan bahan dan pembuatan tidak diperlukan keputusan baru. Perancangan $w e b$ pembelajaran mata kuliah matematika ekonomi ini menggunakan perangkat struktur navigasi dan story board.

\section{Struktur Navigasi}

Struktur navigasi yang digunakan pada web pembelajaran matematika ini adalah bentuk model yang hierarkis. Model ini diadaptasi dari top-down design. Konsep navigasi ini dimulai dari satu page (halaman) yang disebut homepage yang menjadi halaman utama. Dari halaman tersebut dapat dibuat beberapa cabang kehalaman yang lain.

\section{Layout}

Layout adalah adalah pola atau halaman dari sebuah web yang sudah didesain dan disiapkan sedemikian rupa. Penggunaan Layout pada web pembelajaran mata kuliah matematika ekonomi ini akan menggambarkan rangkaian tampilan mulai dari tampilan utama, materi dan latihan soal. Layout yang digunakan pada 
perancangan ini dapat dilihat pada gambar berikut:

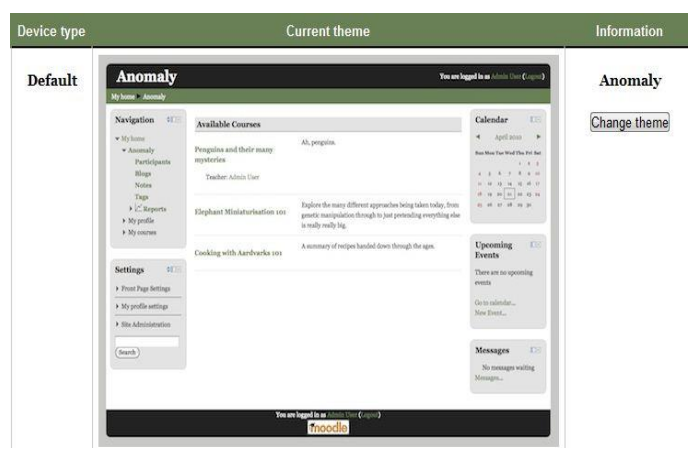

Gambar. 1 Tampilan Awal Website (Homepage)

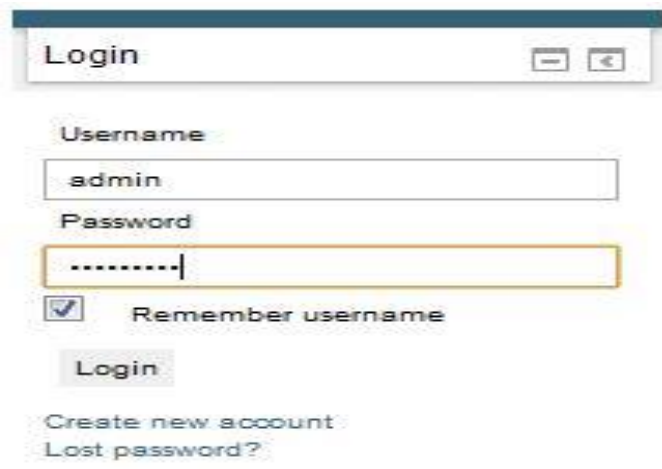

Gambar. 2 Tampilan Login Admin

\section{Pembuatan Desain Web}

Tahapan ini merupakan tahapan seluruh objek web dibuat. Pembuatan web pada tahap ini meliputi pembuatan materi materi deret dan fungsi lineardan latihan soal yang disusun berdasarkan struktur navigasi dan storyboardyang telah didesain.

\section{Testing (uji coba)Web}

Testing dilakukan setelah seluruh materi pengajaran dimasukkan pada tahap pembuatan. Pada tahap ini dapat terlihat sistem pada web yang telah dibuat dapat berjalan baik atau sebaliknya. Dalam penelitian ini ujicoba desain akan dilakukan dalam dua tahapan:

Ujicoba kelayakan web oleh dosen dan pakar yang berkompeten. Uji coba kelayakan oleh user, dalam hal ini mahasiswa semester $\mathrm{V}$
Program Studi Ekonomi Islam FEBI IAIN Bengkulu.

\section{Evaluasi}

Melakukan perbaikan terhadap web pembelajaran yang telah diujicoba, dan perbaikan dilakukan berdasarkan masukan dari pakar yang berkompeten serta user (mahasiswa semester v) pada bagian-bagian tertentu yang dibutuhkan oleh user.

\section{HASIL DAN PEMBAHASAN}

Website e-learning yang dibangun ini berisi materi pelajaran fungsi linier beserta contoh soal dan latihan soal yang telah diuji kelayakannya oleh dosen yang kompeten sehingga website tersebut dapat digunakan oleh user secara offline. Website pada penelitian ini dirancang untuk dapat dijalankan oleh 3 jenis pengguna, yaitu: admin sebagai pengendali seluruh isi website, dosen sebagai pengguna yang dapat memasukkan materi pembelajaran, dan mahasiswa sebagai pengguna yang dapat mengambil informasi dan menyelesaikan tugas yang diberikan oleh dosen.

Setelah menggunakan website sebagai media pembelajaran matematika ekonomi, mahasiswa memberikan penilaian terhadap website pembelajaran yang telah dibuat dengan cara mengisi angket kelayakan website pembelajaran matematika ekonomi. Hasil dari angket penilaian mahasiswa terhadap kelayakan website pembelajaran matematika ekonomi ini ditabulasikan dalam bentuk angka untuk selanjutnya diinterpretasikan dalam bentuk persentase lalu ditafsirkan dengan kalimat.

Peneliti melakukan penelitian di mahasiswa semester v Program Studi Ekonomi Islam, FEBI IAIN Bengkulu 
yang berjumlah 100mahasiswa. Setelah peneliti mengajarkan matematika dengan media website lebih dari lima kali pertemuan, peneliti memberikan tes hasil belajar matematika ekonomi berupa soal pilihan ganda dengan empat alternatif jawaban. Tes yang diberikan telah terlebih dahulu dilakukan uji coba validitas menggunakan Point Biserial, ternyata dari 30 soal yg peneliti berikan didapat 22 soal yang valid, dan 8 soal tidak valid dimana soal yang tidak valid kemudian dibuang. Soal yang valid inilah yang peneliti berikan kepada siswa dan dimasukkan ke dalam website.

Dari data tes hasil belajar mahasiswadiperoleh rentang nilai mulai dari 31,8 sampai 100 dengan rata-rata $=79,39$, median $=83$, modus $=85,23$, varians $=261,333$ dan simpangan baku $=16,166$. Penyajian data dapat dilihat pada tabel berikut:

Tabel 1.Distribusi Frekuensi Hasil Tes Mahasiswa

\begin{tabular}{|c|c|c|c|c|}
\hline \multirow[t]{2}{*}{ No } & \multirow[t]{2}{*}{ Interval } & \multirow[t]{2}{*}{ Batas Nyata } & \multicolumn{2}{|c|}{ Frekuensi } \\
\hline & & & $\begin{array}{c}\text { Absolu } \\
t\end{array}$ & $\begin{array}{c}\text { Relatif } \\
(\%)\end{array}$ \\
\hline 1 & $89-100$ & $88,5-100,5$ & 24 & 29,630 \\
\hline 2 & $77-88$ & $76,5-88,5$ & 36 & 44,444 \\
\hline 3 & $65-76$ & $64,5-76,5$ & 20 & 11,111 \\
\hline 4 & $53-64$ & $52,5-64,5$ & 5 & 3,704 \\
\hline 5 & $41-52$ & $40,5-52,5$ & 10 & 7,407 \\
\hline 6 & $29-40$ & $28,5-40,5$ & 5 & 3,704 \\
\hline & Jumlah & & 100 & 100,00 \\
\hline
\end{tabular}

Pada tahap ini website yang telah dibuat diuji coba kepada user(dosen dan semester V Program Studi Ekonomi Islam, FEBI IAIN Bengkulu). Berdasarkan uji coba yang telah dilakukan, dinyatakan bahwa elemen-elemen website yang digunakan telah memenuhi syarat untuk dikatakan sebagai sebuah website. Hal ini ditandai oleh materi yang disediakan cukup lengkap dan system website yang telah dibuat dapat berjalan dengan baik, sehingga website yang telah dibuat layak untuk digunakan sebagai alternatif media pembelajaran matematika ekonomi.

Uji coba yang dilakukan kepada mahasiswa dilakukan dengan cara seluruh mahasiswa diberikan kesempatan untuk menggunakan website pembelajaran matematika ekonomi yang telah dibuat kemudian mengisi angket uji kelayakan website sebanyak 10 item pertanyaan mencakup keterbacaan website, kemudahan penggunaan website dan disain website. Hasil angket yang diperoleh dari100 user dapat dilihat pada tabel berikut ini:

Tabel 2. Hasil Uji Coba Kelayakan Multimedia oleh Mahasiswa

\begin{tabular}{|c|c|c|c|}
\hline \multirow{2}{*}{ No } & \multirow{2}{*}{ Item Pertanyaan } & \multicolumn{2}{|c|}{ Jumlah } \\
\hline & & $\begin{array}{l}\text { Frekuen } \\
\text { si }\end{array}$ & $\begin{array}{c}\text { Persenta } \\
\text { se } \\
(\%) \\
\end{array}$ \\
\hline $\begin{array}{l}1 \\
.\end{array}$ & $\begin{array}{l}\text { Apakah teks yang } \\
\text { ada pada website } \\
\text { pembelajaran } \\
\text { matematika } \\
\text { ekonomi ini mudah } \\
\text { dibaca? } \\
\text { - Ya } \\
\text { - Tidak } \\
\end{array}$ & $\begin{array}{l}75 \\
25\end{array}$ & $\begin{array}{l}75 \\
25\end{array}$ \\
\hline $\begin{array}{l}2 \\
.\end{array}$ & $\begin{array}{l}\text { Apakah gambar } \\
\text { yang ada pada } \\
\text { website } \\
\text { pembelajaran } \\
\text { matematika } \\
\text { ekonomi ini dapat } \\
\text { dilihat dengan } \\
\text { jelas? } \\
\text { - Ya } \\
\text { - Tidak }\end{array}$ & $\begin{array}{l}69 \\
31\end{array}$ & $\begin{array}{l}69 \\
31\end{array}$ \\
\hline $\begin{array}{l}3 \\
.\end{array}$ & $\begin{array}{l}\text { Apakah gambar } \\
\text { yang ada pada } \\
\text { website } \\
\text { pembelajaran } \\
\text { matematika } \\
\text { ekonomi ini } \\
\text { mendukung } \\
\text { materi segiempat }\end{array}$ & $\begin{array}{l}84 \\
16\end{array}$ & $\begin{array}{l}84 \\
16\end{array}$ \\
\hline
\end{tabular}




\begin{tabular}{|c|c|c|c|}
\hline & $\begin{array}{l}\text { yang disediakan? } \\
-\quad \text { Ya } \\
-\quad \text { Tidak }\end{array}$ & & \\
\hline $\begin{array}{l}4 \\
.\end{array}$ & $\begin{array}{l}\text { Apakah materi } \\
\text { pilihan yang ada } \\
\text { pada website } \\
\text { pembelajaran } \\
\text { matematika } \\
\text { ekonomi ini sudah } \\
\text { lengkap? } \\
\text { - Ya } \\
\text { - Tidak }\end{array}$ & $\begin{array}{l}70 \\
30\end{array}$ & $\begin{array}{l}70 \\
30\end{array}$ \\
\hline 5 & $\begin{array}{l}\text { Apakah materi } \\
\text { pelajaran yang ada } \\
\text { pada website } \\
\text { pembelajaran } \\
\text { matematika } \\
\text { ekonomi ini mudah } \\
\text { diakses? } \\
\text { - Ya } \\
\text { - Tidak }\end{array}$ & $\begin{array}{l}72 \\
28\end{array}$ & $\begin{array}{l}72 \\
28\end{array}$ \\
\hline $\begin{array}{l}6 \\
.\end{array}$ & $\begin{array}{lr}\text { Apakah tampilan } \\
\text { yang ada pada } \\
\text { website } & \\
\text { pembelajaran } & \\
\text { matematika } & \\
\text { ekonomoi ini } \\
\text { menarik untuk } \\
\text { dilihat? } \\
\text { - Ya } \\
\text { - Tidak }\end{array}$ & $\begin{array}{l}78 \\
22\end{array}$ & $\begin{array}{l}78 \\
22\end{array}$ \\
\hline $\begin{array}{l}7 \\
\text {. }\end{array}$ & $\begin{array}{l}\text { Apakah } \\
\text { paduanwarnakesel } \\
\text { uruhan yang ada } \\
\text { pada website } \\
\text { pembelajaran } \\
\text { matematika } \\
\text { ekonomi } \\
\text { inibagus? } \\
\text { - Ya } \\
\text { - Tidak }\end{array}$ & $\begin{array}{l}83 \\
17\end{array}$ & $\begin{array}{l}83 \\
17\end{array}$ \\
\hline 8 & $\begin{array}{l}\text { Apakah } \\
\text { penempatan objek } \\
\text { yang ada pada } \\
\text { website } \\
\text { pembelajaran } \\
\text { matematika } \\
\text { ekonomi ini sudah } \\
\text { sesuai? } \\
\text { - Ya } \\
\text { - Tidak }\end{array}$ & $\begin{array}{l}71 \\
29\end{array}$ & $\begin{array}{l}71 \\
29\end{array}$ \\
\hline 9. & $\begin{array}{l}\text { Menurut anda } \\
\text { perlukah website } \\
\text { pembelajaran } \\
\text { matematika }\end{array}$ & & \\
\hline
\end{tabular}

\begin{tabular}{lcc}
\hline ekonomi seperti & & \\
ini digunakan & 95 & 95 \\
dalam & 5 & 5 \\
pembelajaran & & \\
matematika? & & \\
$-\quad$ Ya & & \\
- Tidak & & \\
\hline 10. Jika perlu, di & \\
manakah website & & \\
pembelajaran & & \\
matematika & & \\
ekonomi ini dapat & 15 & 15 \\
digunakan? & 17 & 17 \\
- Rumah & 68 & 68 \\
- Sekolah & & \\
- Keduanya & & \\
\hline
\end{tabular}

\section{Hakikat Belajar}

Sebagian orang berpendapat bahwa belajar adalah mengumpulkan atau menghafalkan fakta-fakta yang tersaji dalam bentuk informasi atau materi pelajaran. Disamping itu adapula sebagian orang yang memandang belajar sebagai latihan seperti yang terlihat pada latihan membaca dan menulis.

Kegiatan belajar tidak hanya terbatas pada usaha untuk mendapatkan ilmu pengetahuan, tetapi juga mencakup segala usaha yang dapat menyebabkan perilaku atau pribadi seseorang berdasarkan pengalaman, sebagaimana diungkapkan oleh Slameto: "Belajar adalah suatu proses yang dilakukan individu untuk memperoleh suatu perubahan tingkah laku yang baru secara keseluruhan sebagai hasil pengalaman individu itu sendiri, dalam interaksinya dengan lingkungan.

\section{Teknologi Informasi dan Komunikasi}

Perkembangan teknologi selalu mempunyai peran yang sangat tinggi dan ikut memberikan arah perkembangan dunia pendidikan. Dalam sejarah perkembangan pendidikan, teknologi informasi 
adalah bagian dari media yang digunakan untuk menyampaikan pesan ilmu pada orang banyak, mulai dari teknologi percetakan beberapa abad yang lalu, seperti buku yang dicetak, hingga media telekomunikasi seperti, suara yang direkam pada kaset, video, televisi, dan CD.

Teknologi informasi dan komunikasi adalah subjek yang luas yang berkenaan tentang teknologi dan aspek lain tentang bagaimana melakukan manajemen dan pemrosesan informasi, umumnya padaperusahaan besar. Teknologi informasi saat ini yang salah satunya adalah internet, mengarahkan sejarah teknologi pendidikan pada alur yang baru. Layanan online dalam pendidikan baik bergelar maupun tidak bergelar pada dasarnya adalah memberikan pelayanan pendidikan bagi pengguna (mahasiswa) dengan menggunakan internet sebagai media.

Layanan online ini dapat terdiri dari berbagai tahapan dari proses program pendidikan seperti: pendaftaran, test, pembelajaran, penugasan, pembahasan, ujian, penilaian, diskusi, pengumuman, dll. Pendidikan jarak jauh dapat memanfaatkan teknologi internet secara maksimal, dapat memberikan efektifitas dalam hal waktu, tempat dan bahkan meningkatkan kualitas pendidikan.

\section{Pengertian Pendidikan Jarak Jauh}

Pendidikan jarak jauh adalah sekumpulan metoda pengajaran dimana aktivitas pengajaran dilaksanakan secara terpisah dari aktivitas belajar. Pemisah kedua kegiatan tersebut dapat berupa jarak fisik, misalnya karena mahasiswa bertempat tinggal jauh dari lokasi institusi pendidikan. Pemisah dapat pula jarak non-fisik yaitu berupa keadaan yang memaksa seseorang yang tempat tinggalnya dekat dari lokasi institusi pendidikan namun tidak dapat mengikuti kegiatan pembelajaran di institusi tersebut. Keterpisahan kegiatan pengajaran dari kegiatan belajar adalah ciri yang khas dari pendidikan jarak jauh.

\section{Pendidikan Jarak Jauh Berbasis Web Secara Online}

Jika kembali ke konsep dasar pada suatu sistem pendidikan tradisional yang dilakukan saat ini, para mahasiswa dan dosen bertemu pada suatu tempat dan waktu tertentu. Sistem pendidikan tradisional ini kelak akan bergeser kepada pendidikan jarak jauh dengan dilandasi bahwa agak sulit untuk mengumpulkan peserta kursus, training atau pendidikan pada satu waktu dan tempat tertentu sedangkan peserta tersebar di wilayah yang berbeda-beda dan pada dasarnya materi-materi yang seharusnya disampaikan di kelas, dapat diberikan tanpa kehadiran para mahasiswadan dosen secara langsung dikelas.

\section{SIMPULAN}

Berdasarkan deskripsi data dan pembahasan, dapat disimpulkan bahwa:

1. Pembelajaran dengan website pembelajaran matematika ekonomi dapat menumbuhkan antusias mahasiswa dan semangat belajar, sehingga muncul aktifitas mahasiswa yang lebih baik. Karena pembelajaran ini menyajikan media yang baru dan menyenangkan serta menarik bagi mahasiswa, serta dapat mengurangi rasa bosan sehingga mahasiswa dapat mempelajari matematika ekonomi denganbaik.

2. Mahasiswa memiliki respon yang positif terhadap website 
pembelajaran matematika ekonomi, sehingga mahasiswa termotivasi dalam mempelajari matematika ekonomi. Hal ini dapat dilihat dengan 95 mahasiswa menyatakan bahwa website perlu digunakan dalam pembelajaran matematika ekonomi. Kesesuaian gambar dengan materi pelajaran yang disampaikan akan membantu mahasiswa dalam memahami pelajaran. Hal ini ditandai dengan 84 mahasiswa menyatakan bahwa gambar yang ada pada website yang dibuat mendukung materi segiempat. Dengan demikian, perangkat lunak (software) moodle dapat dijadikan sebagai software dalam pengembangan model pembelajaran berbasis website yang cukup menarik untuk berbagai macam pelajaran terutama matematika ekonomi jika, hal ini dilihat dari website pembelajaran matematika ekonomi yang dibuat dengan software moodle dapat menyajikan bahan ajar secara menarik.

\section{DAFTAR PUSTAKA}

Akbar, A. (2006). Panduan Cepat Menguasai Teknologi Informasi dan Komunikasi. Semarang: PT.Gava Media

Arfianto, T. (2017). Penerapan ELearning Berbasis Moodle Menggunakan Metode Problem Based Learning di SMK Negeri 1 Pasuruan, Jurnal Smatika Stiki Malang

Handayanto, A. (2015). Pembelajaran E-Learning Menggunakan Moodle pada Mata Kuliah Metode Numerik, Jurnal Informatika UPGRIS Semarang

Poerdaminta, W. J. S. (2003). Kamus Besar Bahasa Indonesia. Cet. Ke-8. Jakarta: Balai Pustaka
Porter, D. B., \& Hernacki, M. (2002). Quantum Learning, Bandung: Penerbit Kaifa

Prayitno, M. (2012). Keefektifan Pembelajaran E-Learning Berbasis Website pada Mata Kuliah Teori Bilangan di IKIP PGRI Semarang. Jurnal Matematika dan Pendidikan, FMIPA Unsoed

Setiawan, R. (2013). E-Learning Moodle Untuk Meningkatkan Motivasi Dan Hasil Belajar Teknologi Informasi Dan Komunikasi. Jurnal COPE UNY Yogyakarta

Slameto, S. (1998). Belajar dan Faktor-Faktor yang Mempengaruhinya, Jakarta: Bumi aksara

Sobur, A. (2003). Psikologi Umum, Bandung: Pustaka Setia

Suherman, E. (2003). Strategi Pembelajaran Matematika Kontemporer. Bandung: Universitas Pendidikan Indonesia

Sutisna, D. (2007). 7 Langkah Mudah Menjadi Webmaster, Media Kita, Jakarta

Syah, M. (2003). Psikologi Pendidikan Dengan Pendekatan Baru, Bandung: PT Remaja Rosdakarya

UU RI no.12. (2003). Sistem Pendidikan Nasional, Jakarta. CV. Mini Jaya Abadi 